\title{
水潤滑軸受オーバハングロータの非線形振動*
}

$$
\begin{aligned}
& \text { 山 和 幸*1, 井上知 昭*1 } \\
& \text { 高 } \text { 亨 之*1, 坪 内 邦 良*2 }
\end{aligned}
$$

\section{Non-Linear Vibration of an Overhang Rotor in Water-Lubricated Bearings}

Kazuyuki YAMAGUCHI*3, Tomoaki INOUE, Michiyuki TAKAGI and Kuniyoshi TSUBOUCHI

\footnotetext{
${ }^{* 3}$ Mechanical Engineering Research Laboratory, Hitachi Ltd., 502 Kandatsu, Tsuchiura-shi, Ibaraki, 300-0013 Japan
}

\begin{abstract}
Using water-lubricated bearings for turbo-machinery is useful for reducing bearing loss. It is important, however, to achieve rotor vibration reliability because the damping coeficient of the bearing that is placed on the far side of the overhung part is reduced. We conducted vibration tests on a motor-mounted rotor to understand the vibration characteristics of this type of rotors. We observed a jump phenomenon of vibration amplitude and sub-harmonic resonance in these tests. We considered that these phenomena were caused by the non-linear characteristics of the water lubricated bearings, and we verified this assumption by using numerical simulations. The calculated results agreed well with the measured results, and we learnt some methods for reducing the non-linear vibration.
\end{abstract}

Key Words: Vibration of Rotating Body, Overhung, Non-Linear, Finite Element Method

\section{1. 緒言}

環境問題への関心が高まる中, ターボ機械に対す る小型化, 高効率化の要求が高まっており, ロータの 回転速度の高速化，軸受損失などの機械損失の低减が 求められている.すずり軸受の損失低隇のためには, 水や空気などの粘度の低い流体を潤骬材として使用す ることが有効であるが, 軸受の減衰係数が減少すると ともに, 軸浮上量减少により軸受剛性, 減衰係数の非 線形性が增加する. 特に, 軸受スパン外側一方に翼車 などを配置するオーバハングロータでは，オーバハン グ部反対側軸受の荷重減少により軸受の減衰係数が減 少し,オーバハング部側軸受の荷重増加により軸受剛 性, 減衰係数の非線形性か増加するため, 分数調波共 振などの非線形振動の抑制が重要な課題になる。

スクイズフィルムダンパの接触，転がり軸受のガ 夕など，ロー夕支持剛性の非線形性に起因する軸振動 挙動については多数の研究報告がなされており, 文献

（1）に詳しく解説されている ${ }^{(1)}$. Gadangi らは油潤 滑ティルティングパッド軸受に支持されたロータを対

* 原稿受付 2004 年 4 月 26 日.

*1 正員, (株) 日立製作所機械研究所( - 300-0013 土浦市神立 町 502).

*2 正員, (株) 日立製作所電力電機開発研究所(画 312-0034 U たちなか市堀口 832-2).

E-mail : yamaguti@merl.hitachi.co.jp
象に軸受油膜と軸振動の連成解析を実施し，線形解析 及び準静的解析結果との比較により解析手法の有効性 を示している(2). しかし， 1 軸 1 円板剛体ロータを 対象としており，実測結果との比較もなされていない ことから，実機で使用されるロー夕の非線形振動特性 評価という点では必ずしも十分とはいえない.

本報告では，水潤滑ティルティングパッド軸受を 用いた試験装置を試作し，回転試験により振動現象を 評価した。この結果, 軸受減衰係数が十分に大きい油 潤滑軸受では発生しなかった振動振幅のジャンプ現象 や分数調波共振か溌生した。これらの現象のメカニズ ムを検討するために，軸支持剛性，減哀係数の非線形 特性データベースを用いた軸振動数值シミュレーショ ンを実施した. 得られた結果から非線形ロー夕の設計 法について述べる.

\section{2. 実験方 法}

試験ロー夕を図 1 に示す、ロー夕はモー夕部と翼 部で構成されている。モー夕部には永久磁石か内蔵さ れており, 回転試験装置のステータと合わせて永久磁 石モータを形成している. 回転試験では, インバータ の回転速度指令值を变化させることにより昇速及ひ降 速運転を行なった。

試験ロータのモー夕部の両端には軸受が配置され, 
軸受スパンの外側には翼部が配置されている，翼部は 翼車の慣性を模した擬似円板としている，翼部側の軸 受を軸受 2 , 反対側を軸受 1 と呼ぶことにする。

回転試験装置の軸受諸元を表 1 に示す。両軸受と も 4 パッドの水潤滑ティルティングパッド軸受を使用 している．軸受2はスラスト軸受を兼ねている．軸受 1 の荷重は軸受 2 の荷重の 0.1 倍と非常に小さくなっ ている. 軸振動の安定性を確保するために両軸受の外 周側に O リングで支持したスクイズフィルムダンパ を設けている。 スタイズフィルムダンパの作動流体に は軸受潤滑水を流用している。

回転試験装置では，両軸受付近に設置した渦電流 式変位計を用いて，上下方向及び水平方向の軸振動変 位を計測した．本報告では軸受 2 の上下方向振動の結 果を示す。

回転パルスは, 軸受 1 側の軸端に取り付けた円板の ザグリ穴を，渦電流式变位計で検出することにより計 測した．計測信号の処理にはベントリネバダ社製回転

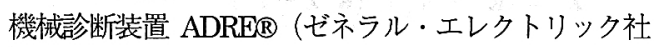
の登録商標）を用いた。

\section{3. 実 験 結 果}

3.1 振動振幅のジャンプ現象昇速時の回転速 度と回転速度成分振動振幅の関係を図 2 に示す。横軸 は回転速度であり，縦軸は振動振幅である. 回転速度 $3601 / \mathrm{s}$ 付近で, 回転速度成分の振幅が $30 \mu \mathrm{m}$ から 80 $\mu \mathrm{m}$ へと急激にジャンプしたため, 昇速を中止した.

フィールドバランスを実施し，回転速度 $3601 / \mathrm{s}$ 付 近の振幅を低減したときの図 2 と同様の実測結果を図 3 に示す。 バランス修正により回転速度 $3501 / \mathrm{s}$ におけ る振幅は $31 \mu \mathrm{m}$ 加 $22 \mu \mathrm{m}$ 一と減少し, 回転速度 $3601 / \mathrm{s}$ 付近でのジャンプ現象は発生しなくなった. 図 3 からわかるように, 1 次危険速度は $911 / \mathrm{s}, 2$ 次危険 速度は $388 \mathrm{1} / \mathrm{s}$ である. 振動振幅のジャンプ現象は 2 次危険速度より若干低い回転速度で発生している。

Rotor length $800 \mathrm{~mm}$

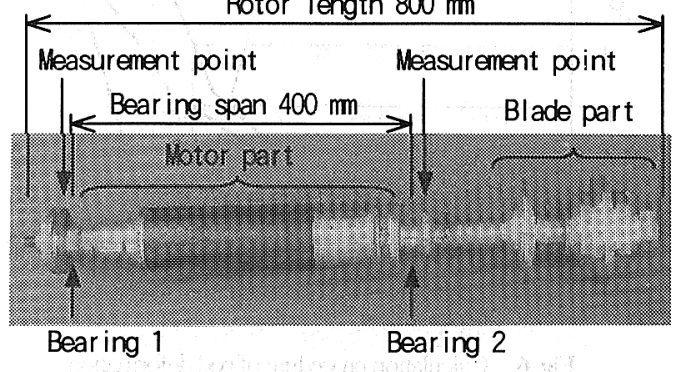

Fig. 1 Testrotor
3.2 分数調波共振 昇速時のカスケード図計測 結果を図 4 に示す。本ロー夕系には $100 \mathrm{~Hz}$ 付近 (65 $\sim 135 \mathrm{~Hz}$ ）に固有振動数があるため，回転速度が固有 振動数の整数倍に近い200 1/s 付近 $(127 \sim 2571 / \mathrm{s})$ 及 び $4001 / \mathrm{s}$ 付近（370 403 1/s）で分数調波共振が発生

Table 1 Bearing specification

\begin{tabular}{c|c|c}
\hline \hline Item & Bearing 1 & Bearing 2 \\
\hline Type & Tilting pad & $\begin{array}{c}\text { Tilting pad } \\
\text { with thrust } \\
\text { bearing }\end{array}$ \\
\hline Load Direction & \multicolumn{2}{|c}{ Load Between Pad } \\
\hline Lubricant & \multicolumn{2}{|c}{ Water } \\
\hline Pad number & \multicolumn{2}{|c}{4} \\
\hline Shaft diameter & \multicolumn{2}{|c}{$40 \mathrm{~mm}$} \\
\hline Width & \multicolumn{2}{|c}{$10 \mathrm{~mm}$} \\
\hline $\begin{array}{c}\text { Pad curvature } \\
\text { radius }\end{array}$ & \multicolumn{2}{|c}{$20.05 \mathrm{~mm}$} \\
\hline Diameter clearance & $0.05 \mathrm{~mm}$ & $0.1 \mathrm{~mm}$ \\
\hline Load (ratio) & 0.1 & 1 (Base)
\end{tabular}

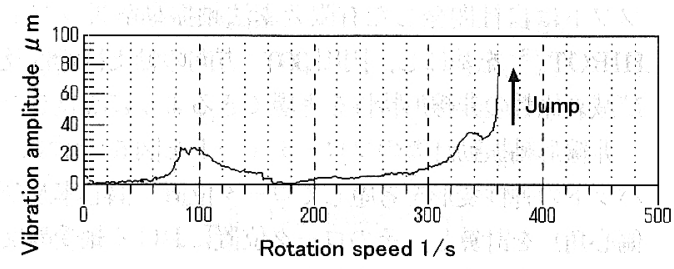

Fig. 2 Rotation speed vs. measured vibration amplitude of rotation frequency component

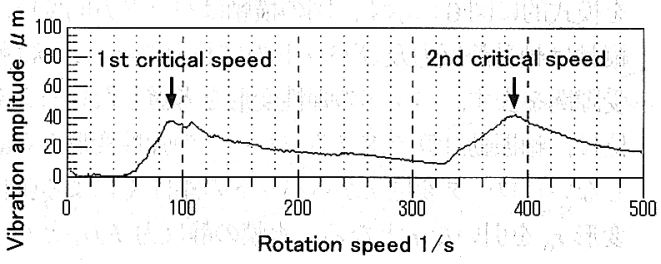

Fig. 3 Rotation speed vs. measured vibration amplitude of rotation frequency component on balanoed condition

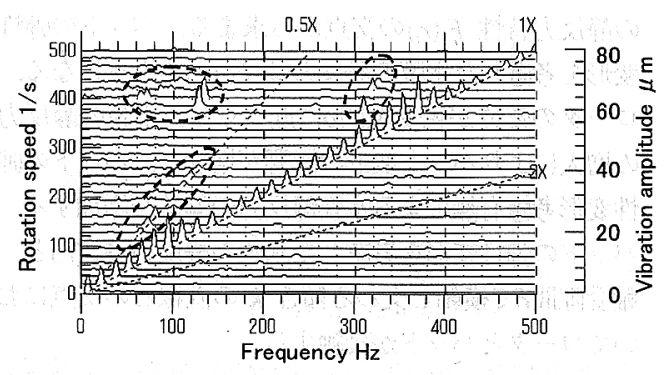

Fig.4 Measured cascade diagram 
し，固有振動数成分の振幅力増加している. また，回 転速度 $400 \mathrm{1} / \mathrm{s}$ 付近では, 固有振動数成分と回転速度 成分による和差調波振動も発生している. 回転速度 $4001 / \mathrm{s}$ 付近に扔ける分数調波共振周波数の回転次数は 16 次及び $1 / 3$ 次である. 分数調波共振発生時の低周 波成分の振幅は回転速度成分の振幅と同等以上であり， 低周波振動を低减することか望ましい。

\section{4. 計 算 方 法}

振動振幅のジャンプ現象は漸軟ばね特性もしくは 予圧を与えた漸硬ばね特性を有する非線形振動系で発 生することが知られている。 また，非線形ばね特性に より分数調波共振力溌生する ${ }^{(1)}$. これらの現象は従 来の油軸受ではあまり問題になっていないことから， 本ロータでは水を利用した軸支持部の剛性, 減哀係数 の非線形特性により異常振動が発生したと考えられる. 非線形振動の原因究明のため, 水潤滑軸受及びス クイズフイルムダンパの非線形岡性及び非線形咸衰特 性を考慮した軸振動時刻歴応答解析を実施した. 解析 ソフトは自社開発した有限要素法軸振動解析ソフト HIROT ${ }^{(3)}$ を基にし, 円周 $360^{\circ}$ 方向の軸支持剛性及 び減衰係数の非線形特性を考慮できるように改良した。

非線形軸振動計算のフローチャートを図 5 に示す. パッドの弾性変形を考慮してロー夕位置（偏心率及び 偏心角）を計算し，そのロー夕位置における軸受静反 力及び咸衰係数を予め計算した軸受データベースから 読み取ることにより軸受反力を計算した.

パッドの弾性変形を考慮したロー夕位置の計算方法 を模式的に図 6 に示す. 図の横軸はパッド方向变位, 絴軸は軸受静反力及びパッドのばね力であり， $\delta$ は軸 受隙間を表す。 パッドの弾性変形を考慮したロー夕恋 位は, 軸振動計算で求まる（パッドの弾性変形を考慮 しない） ロー夕変位 $r_{i}$ からパッドの剛性 $k_{c}$ による弾性 変形 $r_{c i}$ を引いた $r_{i}^{\prime}$ となる. 水膜の静反力 $F_{s}\left(r_{i}\right)$ とパッ ド剛性の反力が釣り合うと仮定すると, パッドの弾性 変形を考慮したロー夕変位 $r_{i}^{\prime}$ は, 軸振動計算で求まる ロー夕変位 $r_{i}$ で横軸と交わる傾き $-k_{c}$ の直線と, 軸受 の静反力特性 $F_{s}\left(r_{i}\right)$ の交点から求まる. パッドの弾性 変形を考慮した水膜の静反力は $F_{s}{ }^{\prime}\left(r_{i}\right)$ のようになる. ロー夕の変位が軸受隙間 $\delta に$ 近づくと, 水膜の静反力 の増大によりパッド変形の影響が増加し，パッドの弾 性変形考虑有無による水膜静反力の偏差が増加する. パッドの弾性变形を考慮した水膜の静反力 $F_{s}{ }^{\prime}\left(r_{i}\right)$ と, 軸受隙間 $\delta$ で横軸と交わる傾き $k_{c}$ の直線との交点にお いてロータとパッドが接触する.

図6のパッド弾性変形を考慮したパッド方向ロー夕
位置計算方法を，上下方向及び水平方向の自由度を有 する変位ベクトルに拡張する. 水膜の静反力とパッド 剛性による反力の釣合いは次式で表される.

$$
\begin{aligned}
& \mathbf{k}_{c} \mathbf{z}_{c}=\mathbf{k}_{s} \mathbf{z}^{\prime}+\mathbf{f}_{s} \\
& \mathbf{z}^{\prime}=\mathbf{z}-\mathbf{z}_{c}
\end{aligned}
$$

ここに, $\mathbf{z}_{\mathrm{c}}$ は各パッドの弾性変形ベクトルの総和, $\mathbf{k}_{s}$ 及び $\mathbf{f}_{s}$ は水膜の静反力の局所的な剛性マトリクス 及び切片ベクトルであり, $\mathbf{z}$ はパッドの弾性変形を 考慮したロー夕変位べクトル, $\mathrm{z}$ はパッドの弾性変 形を考虑しないロー夕恋位べクトルである． $\mathbf{k}_{c}$ は軸 受全周のパッド剛性マトリクスである. 4 枚のパッ ドのうちロー夕位置から遠い 2 枚のパッドの弾性変 形は無視できるので, $\mathbf{k}_{\mathrm{c}}$ にはロー夕位置に近い 2 枚 のパッドの剛性を考慮する. 式（1）及び式（2）を $\mathbf{z}_{c}$ について解くと, 次式が得られる.

$$
\mathbf{z}_{c}=\left(\mathbf{k}_{c}+\mathbf{k}_{s}\right)^{-1}\left(\mathbf{k}_{s} \mathbf{z}+\mathbf{f}_{s}\right)
$$

式（3）からパッドの弾性変形 $\mathbf{z}_{c}$ は, パッドの変形を 考慮しないロー夕位置における水膜の静反力ベクトル， パッド剛性, 及び水膜剛性から求まることがわかる.

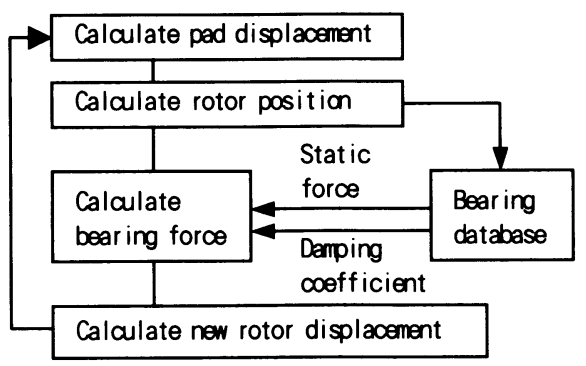

Fig. 5 Flowchart for non-linear vibration analysis

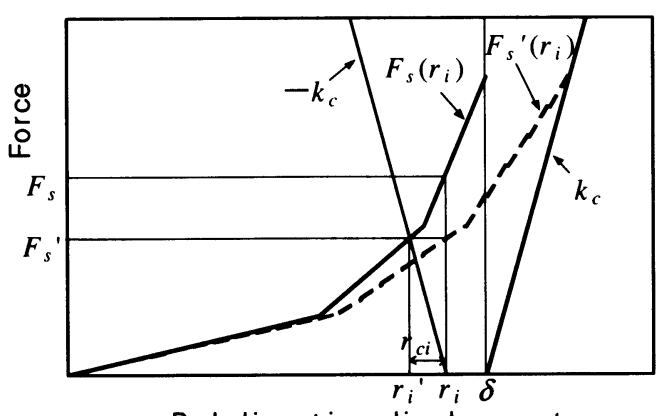

Pad direction displacement

Fig. 6 Calculation procedure of pad deformation 
但し，図6からわかるように，式（3）の $\mathbf{k}_{s}$ 及び $\mathbf{f}_{s}$ は, 弾性変形を考慮したロー夕变位 $\mathbf{z}$ (図6の $r_{i}^{\prime}$ )におけ る值を用いる必要がある。本論文ではパッド 1 枚の剛 性を $10^{9} \mathrm{~N} / \mathrm{m}$ とした。

スクイズフィルムダンパでは静反力が発生しないた め, 減衰係数のデータベースを用いて水膜反力を求め た. また，スクイズフィルムダンパのばね定数は，偏 心率が 1 以下の場合は O リングのばね定数，偏心率 が 1 以上の場合は金属面間の接触剛性とした，接触剛 性は○リング剛性の10倍とした.

軸受及びスクイズフィルムダンパの静反力及び咸衰 係数データベースは，潤滑理論 (4)による軸受解析ソ フトを用いて, 偏心方向に 16 点, 円周方向に 36 点計 算した. 偏心率 1 付近における水膜剛性及び減衰係数 の非線形性か漒く，多項式を用いた補間を行なうと， 真値との䛊差が増大するため, 軸受特性の補間には線 形補間を用いた。回転速度 $400 \mathrm{l} / \mathrm{s}$ に㧍ける軸受 2 の 静反力の絶対值を図 7 に示す. 図の $0^{\circ}$ 方向が軸受の 下方向（荷重方向）である. 偏心率が 1 に近づくと, パッド位置において静反力が急激に増大寸る。ロータ の静的釣合い位置は $0^{\circ}$ 付近であるため, 回転速度が 低く，偏心率が 1 に近いときは，円周方向に剛性の非 線形性か漒いことがわかる。

軸振動の時刻歴応答解析には擬モーダル法 ${ }^{(3)}$ を用 いた. 計算には軸受部の単位変位による静変形モード, 軸受部の単位速度变位による変形モード, 及び軸受部 を固定した6次までの曲け固有振動モードを使用した。 計算モデルを図 8 に示す、ロー夕は梁要素でモデル 化した，自由支持固有振動数を実測し，計算結果と実 測結果が一致するようにロー夕剛性を同定した．また， 危険速度の計算結果が実測結果と一致するように，又 クイズフィルムダンパの O リングの剛性を同定した. 本論文では特にことわらない限り，加振力としてロ 一夕の両端に $90^{\circ}$ の位相差を付けて $100 \mathrm{gmm}$ の不釣 合いを付加した. 各回転速度における時刻歴応答解析 を実施し，計算対象時間は振動波形力゙定常になるよう に十分長く取った。

\section{5. 計 算 結 果}

5.1 振動振幅のジャンブ現象 危険速度におけ る振動モードを図 9 に示す. 図中の $\triangle$ 印は軸受位置を 表す. 1 次危険速度の振動モードは剛体モード，2 次 危険速度の振動モードはロータの曲げを伴う振動モー ドである、いずれの振動モードにおいても軸受位置が 節になっていないため, 軸受特性の影響を受ける.

回転速度と回転速度成分振幅計算結果の関係を図
10 に示す. 図の横軸は回転速度, 縦軸は回転速度成 分の振動振幅を示しており, 実線は不釣合いが $100 \mathrm{gmm}$ のとき，破線は不釣合いが 80gmm のときの 計算結果を示している. 不釣合いが $100 \mathrm{gmm}$ のケー スでは，回転速度が 380 1/s のときに振動振幅が急激

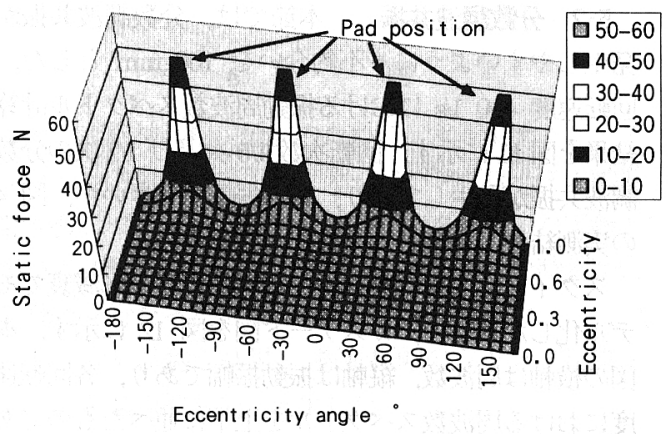

Fig. 7 Static force of the bearing 2

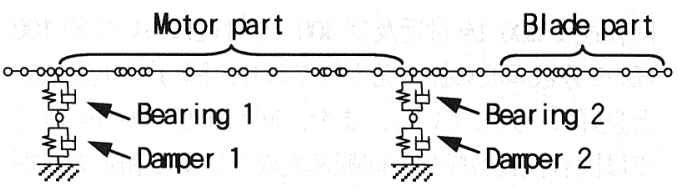

Fig. 8 Calculationmodel

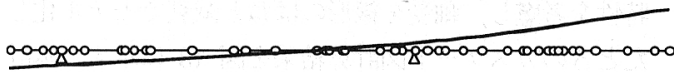

1st critical speed

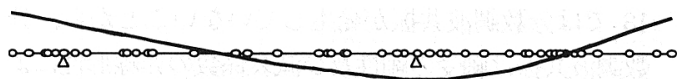

Ind critical speed

Fig.9 Calculated vibration mode on critical speeds

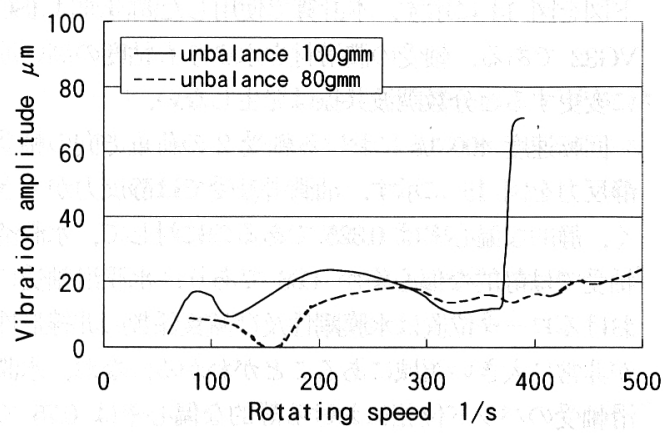

Fig.10 Rotation speed vs. calculated vibration amplitude of motation frequency component 
にジャンプしているが, 不釣合いが 80gmm のときは 振幅のジャンプは無く, 図 2 及び図 3 の実測結果と良 好に一致している。このことから，ロー夕支持剛性及 び減衰係数の非線形性と，比較的大きい不釣合いによ り回転速度成分のジャンプ現象が発生していることが わかった。

5.2 分数啵龷振 本節では, 分数調波共振が 発生しやすいように，不釣合いを $100 \mathrm{gmm}$ とした. 回転速度 $400 \mathrm{l} / \mathrm{s}$ における振動周波数スペクトル計算 結果を図 11 に示す. 回転次数 $1 / 5$ 次及び $1 / 2$ 次の分数 調波共振が発生しており，振動振幅は大きいが，図 4 の実測結果と定性的には良く一致している.

スクイズフィルムダンパを線形ばねと線形減衰でモ デル化したときの，カスケード図を図 12 に示す。本 図の横軸は周波数，縦軸は振動振幅であり，各回転速 度における周波数スペクトルを上下に並べたものであ る. スクイズフィルムダンパの剛性は $\mathrm{O}$ リングの剛 性とし, 隇衰係数は 2 次危険速度の応答倍率計算結果 が実測結果と一致するように同定した. 図 12 では, 回転速度 $200 \mathrm{1} / \mathrm{s}$ 付近及び $400 \mathrm{1} / \mathrm{s}$ 付近において約 100 $\mathrm{Hz}$ の分数調波共振が発生しており, 図 4 の実測結果 と良好に一致している。.また，回転速度 $400 \mathrm{l} / \mathrm{s}$ 付近 では固有振動数成分と回転速度成分による和差調波振 動も発生しており，実測結果と良く一致している.

スクイズフィルムダンパ岡性及び減衰係数の非線形 特性を考慮し，軸受を線形のばねと隇衰でモデル化し たときのカスケード図計算結果を図 13 に示す。本計 算結果では軸受減衰係数を同定していないが，2 次危 険速度の応答倍率は実測値とほほ一致している．図 13 では分数調波共振が発生していないことから, 分 数調波共振は軸受の剛性及び減衰係数の非線形性によ り発生していることがわかる.

スクイズフィルムダンパを線形ばね及び線形隇衰で モデル化し，軸受を油軸受に変更したときのカスケー ド図を図 14 に示す. 本計算で使用した潤滑油は ISO VG32 である. 軸受の潤滑材を水よりも粘度の高い油 に変更すると分数調波共振は発生しない.

回転速度 $4001 / \mathrm{s}$ における軸受 2 の荷重方向の軸受 静反力を図 15 に示す. 油潤滑軸受では静反力が大き く，静的な偏心率は 0.325 であるのに対して，水潤滑 軸受では静的な偏心率が 1.06 であり，水潤滑軸受に おけるロー夕位置は水膜剛性及び隇衰俰数の非線形性 が非常に大きい領域にあることがわかる，なお，水潤 滑軸受のパッド位相における静的な偏心率は 0.75 で あり，静的な平衡位置においてロータとパッドの接触 は発生していない。
以上に述べたように，軸支持剛性，減衰係数の非線 形性を考慮した軸振動シミュレーションにより分数調 波共振の発生メカニズムが明らかになった。そこで, 本計算手法を用いて分数調波共振抑制のための改良構

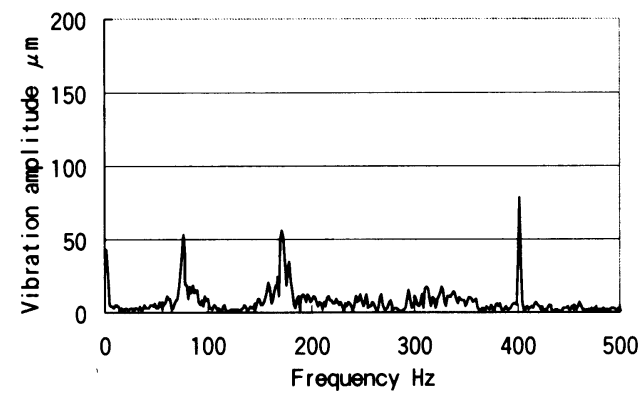

Fig.11 Calculated frequency spectrum of sub-harmonic resonance

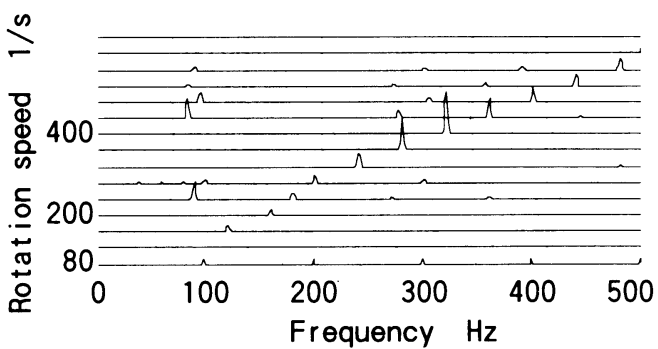

Fig.12 Calculated cascade diagram with linear damper model

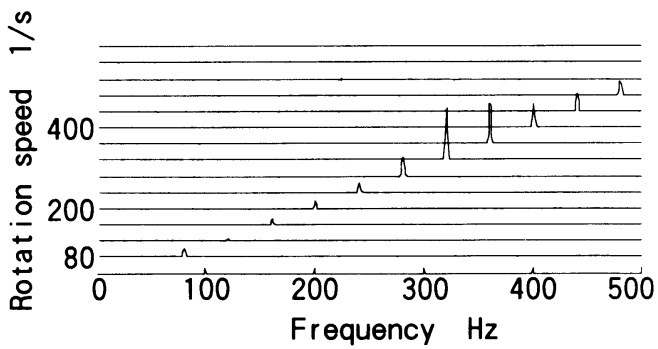

Fig.13 Calculated cascade diagram with linear bearing model

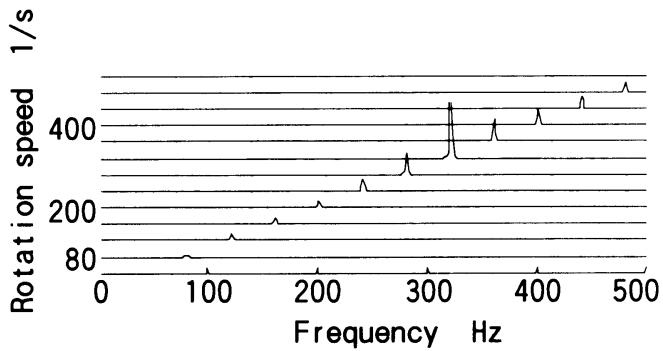

Fig.14 Calculated cascade diagram in oil bearings 


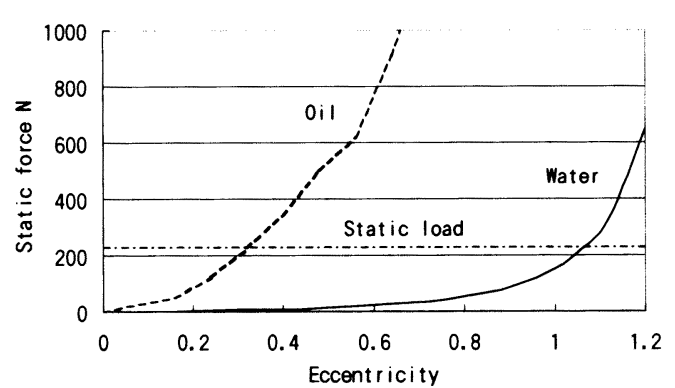

Fig.15 Eccentricity vs. calculated static force of the bearing 2

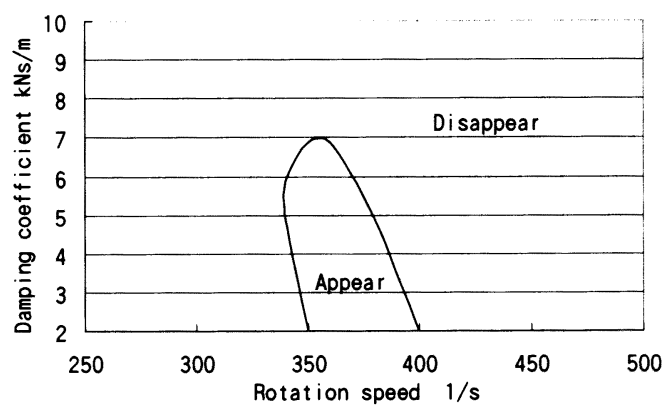

Fig.16 Rotation speed vs. calculated damping coefficient when the sub-harmonic resonance appears

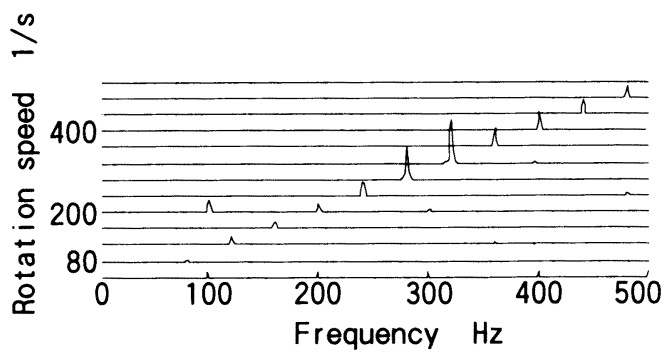

Fig.17 Calculated cascade diagram in load on pad bearings

造について検討する. 軸受 1 及び軸受 2 におけるス クイズフイルムダンパの隇衰係数をパラメータとして, 分数調波共振が発生する回転速度領域を図 16 に示す. スクイズフィルムダンパの減衰係数を増加させると, 分数調波共振の発生領域が若干低速側にずれ, 発生回 転速度範用が小さくなる. 本計算例では, スクイズフ イルムダンパの減衰係数を $7 \mathrm{kNsm}$ 以上にすると分数 調波共振は発生しなくなった。これは, 軸支持减衰の 強化により分数調波共振の不釣合い感度が低下したた めであり, 分数調波共振の抑制には外部隇衰の増加が 有効であることがわかる.

軸受の位相を $45^{\circ}$ 回転させ, 荷重方向をパッド方 向にしたときのカスケード図計算結果を図 17 に示す.
図 12 の結果と比較すると，回転速度か泜く偏心率の 大きい回転速度 $200 \mathrm{v} / \mathrm{s}$ 付近では分数調波共振力゙発生 するが, 回転速度 $4001 / \mathrm{s}$ 付近では分数調波共振が発 生しない. 図7からわかるように, 荷重がパッド方向 に働く場合は水膜剛性の円周方向の非線形性か溺くな るため, 分数調波共振が発生しにくくなると考えられ る.

\section{6. 結 言}

ターボ機械の損失低減のために, 水潤滑ティルティ ングパッド軸受を採用したオーバハングロータの軸振 動挙動について検討した。試験ロータを用いた実験と, 軸支持剛性, 減衰係数の非線形性を考慮した時刻歴応 答解析を行なった結果以下の結論が得られた。

(1) 回転試験の結果, 振動振幅のジャンプ現象, 分数調波共振力溌生した.

（2）軸支持剛性及び減衰係数の円周 $360^{\circ}$ 方向の非 線形特性を考虑できる軸振動解析ソフトを開発 した.

（3）ロー夕支持剛性，減衰係数の非線形性を考慮し て不釣合いによる時刻歴応答解析を実施した結 果, ジャンプ現象, 分数調波共振を再現できた.

（4）本試験ロー夕における分数調波共振は, 水潤滑 軸受剛性及び減衰係数の強い非線形性により発 生していることを示した。

（5）分数調波共振振幅を低減するためには，外部減 衰を強化すること, 軸受の荷重方向をパッド方 向にすることが有効であることがわかった。

$$
\text { 辞 }
$$

本研究は平成 15 年度 NEDO エネルギ使用合理化技 術実用化開発事業の支援に基づいて実施したものであ り,ご支援に感謝する.

\section{文献}

（1）山本敏男 · 石田幸男, 回転機械の力学, コロ ナ社, (2001)， 103.

(2) R. K. Gadangi, ほか 2名, Transient Analysis of Plain and Tilt Pad Journal Bearings Including Fluid Film Temperature Effects, Trans ASME, $J$. Tribol, 118-2April, (1996), 423.

（3）松下修己・ほか 2 名, 擬規準座標変換法によ る回転軸系の振動解析, 機論, 48-431, C(1982), 925-934.

(4) トライボロジ学会編, トライボロジハンドブ ック，養賢堂, (2001), 27. 